\title{
EVOLUTION OF COHESION POLICY. MISSION AND GOVERNANCE ${ }^{2}$
}

\begin{abstract}
Cohesion policy is the major investment vehicle and the most reforming EU budgetary chapter. Its landmark reforms mark key integration processes in the European Union. The present policy paper provides reflections of the dynamics of the main development trends in cohesion policy as determined by global phenomena, namely the economic and financial crisis and the current COVID-19 pandemic. They severely hit the entire EU, inevitably also affecting cohesion policy. The article shows that governance and the mission of cohesion policy has been adjusted to their aftermaths. Reforms introduced new measures and reinforced policy's centralized European profile. Thus, evolution of cohesion policy is an illustration of its transformation from the merely redistributive tool with limited budgetary resources into the full-fledged development policy aimed at safeguarding that EU's visions and goals will be pursued. The paper concludes that a new architecture poses the major challenge for cohesion policy after 2020 as its responsibilities and ever tightening governance continues while its budgets shrinks.
\end{abstract}

Key words: cohesion policy, reforms, mission, governance, thematic oncentration, conditionalities

\section{INTRODUCTION}

EU cohesion policy has evolved into a powerful investment tool backed by significant financial resources. Its evolution is not accidental. It is a deliberate process underpinned by the reforms shaped under specific circumstances of the development in the EU. The last reforms depicted in this paper (2006, 2013, 2020) have taken place under the particularly turbulent times. The crises, namely financial and economic, immigration, Euroscepticism peaking in the Brexit and the recurrent Covid-19 pandemic critically determined a political, economic and

1 Mgr. Igor Jašurek, M.A., University of Economics in Bartislava, Faculty of National Economy, Dolnozemská cesta, Bratislava 1852 35, e-mail: igor.jasurek@euba.sk

2 "This contribution was supported by VEGA grant no. 1/0605/19." 
social development in the EU. Inevitably, cohesion policy could not have been left aside. Its reforms shows critical responses to these phenomena which raised expectations but also produced shortcomings as an important source of lessons learnt. This way, cohesion policy's mission and governance has been shaped over more than a decade.

Paper proceeds as follows. The first chapter serves as an introduction helping to understand cohesion policy by means of its building principles and a transforming mission. Second chapter depicts evolving cohesion policy, specifically its mission and governance as shaped by the three reforms (2006, 2013, and 2020). Conclusions summarize the main arguments.

\section{IS COHESION POLICY?}

There is no uniform understanding of this major EU budgetary chapter. Its mission is articulated in the EU Treaties and historically it pursued goals of economic and social cohesion. The Lisbon Treaty added to the two initial goals also territorial cohesion. Traditionally, cohesion policy has been perceived as striving towards convergence (Baun and Marek, 2014: 2).

As of its inception in 1988, cohesion policy has been the built on five clearly distinctive principles, namely:

- Concentration meaning a focus on an efficient allocation of financial resources;

- Programming as planning of a use of funds;

- Complementarity highlighting that EU financial support is to be viewed as additional to finances originating at national level;

- Partnership expressing active involvement of various stakeholders.

Inception of cohesion policy in 1988 highlighted a transformation from rather an insignificant redistributive tool assisting in regional development of European regions into a full-fledged EU-wide development policy with substantial budgetary resources and objectives with ever closer linked to the EU-wide goals.

\section{EVOLVING EU COHESION POLICY}

Evolution of EU cohesion policy marks the EU integration endeavours, both sides, inside and also enlargement. Inception of cohesion policy in 1988 is perhaps the best fitting example in this respect. It was an outcome of the creation of the single European market embracing the neoclassical idea of unfettered markets. The newly emerging policy aimed at balancing negative effects of economic competition on the open common market through devising a policy mechanism aimed at reducing disparities between the various regions and the 
backwardness of the least-favoured regions (SEA, art. 130). However, it was emphasized already then that the new policy should not serve compensations (Allen, 2005: 218). Importantly, establishing cohesion policy later opened room for further enlargement visions. Thus, it is fair to conclude that cohesion policy represent an engine of the EU integration (Jašurek a Šipikal, 2021b). There is a number of 'turning points' (Manzella and Mendez, 2009) in the evolution of cohesion policy marked by the reforms introducing tools which shaped policy's programming and implementation. In the following part, cohesion reforms (2006, 2013, and 2020) will be presented along with their corresponding ideational background.

\subsection{Shaping the mission}

First of all, ideationally, cohesion policy exceeds its initial scope of supporting regional convergence becoming an EU-wide policy pursuing goals to meet the EU's ambition of being a crucial global player. Evidently, cohesion policy has undergone more significant changes than any other EU policy (Manzella and Mendez, 2009: 20). Thus, policy has also become a testing field for introducing different ideas on the policy's mission reflecting acute needs as settled in the EU political discourse. This trend is notable particularly as of the 2006 reform. For the first time in its history, cohesion policy's mission was linked to the EU wide strategy, namely the Lisbon strategy. It aimed at making the EU 'the most competitive and dynamic knowledge-based economy in the world capable of sustainable economic growth with more and better jobs and greater social cohesion' (European Council, 2000). EU's global ambitions faced then challenges of the 2004 enlargement. Out of the ten new members, eight were central and eastern European post-communist countries with substantially lower economic performance relative to the EU average. Furthermore, the enlargement wave was to repeat again in 2007 with post-communist Bulgaria and Romania joining the EU. This posed a pressure on increasing allocations for cohesion countries. The 2006 reform introduced more stringent thematic concentration linking closely cohesion policy to the Lisbon strategy. Specifically, $30 \%$ of the cohesion envelope was dedicated to environmental infrastructure and combating climate change, $25 \%$ on research and innovation. At the same time, the principle of proportionality was introduced to limit administrative and reporting costs in implementation (Bache, 2014: 250). The reform introduced also audit authority (Manzella and Mendez, 2009: 20) and reinforced the principle of partnership by opening cooperation to relevant civil sector organisations to participate at programming and implementation (Brunazzo, 2016: 30).

The 2006 reform was a result of discussions and disputes over the future course of cohesion policy and the entire EU. In 2004, it became clear that meeting 
the Lisbon's global ambitions would be far more challenging than initially envisaged. The Commission admitted that EU's economic growth was slower than in USA and Asia and the Lisbon Strategy did not seem to be an outmost priority for some member states (European Commission, 2004: 10). The way out of the stagnation was sought by so called Sapir's Report aimed at radical modifications in cohesion policy's architecture. The Report proposed establishing cohesion policy on the two funds only. The first, convergence fund, aimed at low-income member states instead of regions supporting notably administrative capacities and investments into human and physical capital while the second, restructuralisation fund, was meant to boost EU's economic recovery specifically requalification, resettling or underpinning early entrepreneurship activities among people laid off from industry and services (European Commission, 2003: 149150). The responses to the Sapir Report generated two fundamentally different perspectives. In the first group, member states such as the UK and the Netherlands advocated a need at least for partial 'renationalisation' of cohesion policy to simplify its processes and direct the EU funds only at the least developed member states. The other group, mostly cohesion countries, argued that cohesion policy's efficiency could only be ensured under the EU level coordination. Both groups however met in need to simplify cohesion policy notably by reducing number of funds or increasing flexibility in implementation. (Stahl and Luna, 2003: 299300). Michel Barnier, then the Commissioner responsible for regional policy and institutional reform, in his defence of cohesion policy highlighted its European added value (Barnier, 2003). This became the grounds Commission's defensive stance also in future.

The 2013 reform had been carried under the significant integration processes. The Lisbon Treaty introduced the European Parliament as co-legislator along the Council and cohesion policy's mission expanded. The Treaty introduced the third cohesion pillar, territorial cohesion, and cohesion policy became a shared responsibility between the Commission and member states (TFEU, 2016: art. 4). On the other hand, the financial and economic crisis exposed EU's weaknesses against exogenous shocks. Cohesion policy's financial resources served as a substitute for lacking liquidity in combating the crisis and its aftermath. Furthermore, in the face of economic downfall and the failure of the Lisbon strategy, EU also showed to lack a common functioning development vision based on tangible targets linked to EU policies. Such was the case of the strategy Europe 2020 approved by the European Council in June 2010. It introduced the five tangible goals with specific target values to be met by 2020 in areas of employment, research and development, climate change and energy, education, poverty and social exclusion (European Commission, 2010: 7). The explicit link between the EU-wide strategy and cohesion policy was articulated by explicit translation of the Europe 2020's goals into the latter's eleven thematic objectives. Furthermore, 
the reform introduced also complex earmarking with separate allocations setting 2 tier priorities for the European Regional Development Fund and one tier for the European Social Fund. In line with expanding policy's mission to follow also territorial cohesion, integrated territorial instruments were introduced to meet the needs of different territorial levels. Thus, the territorial dimension was recognized as a key component in regional development as it was close to citizens' needs (Ahner, 2009: 4) and cohesion policy was best equipped to meet those needs.

A changing approach towards policy's more strategic expression was part of a process which led to the elaboration of the Barca report (2009). Then, the Report foreran the most important cohesion reform which was part of the trend to increase policy's EU-wide relevance and its primacy as the most important investment tool supporting Union's strategic economic priorities (Baun and Marek, 2014: 69). Barca Report introduced the place-based approach to cohesion policy. 'Place-based approach (PBA) demonstrated a bold ambition to provide a new reformed course for cohesion policy addressing...feasibility of reconciled pursuance of efficiency and equity, relevance of place/territory for regional development and a nature of transformation of cohesion policy' (Jašurek, 2020a: 313). PBA attempted to provide tailor made solutions where one-size fits-all approaches failed (Barca et al., 2012, Farole et al. 2011). According to the Barca Report, failure of the Lisbon Agenda was attributed to European regions' inability to fully tap their potential. This made the case for utilizing the PBA in cohesion policy. Barca Report specifically criticized cohesion policy's lacking strategic focus, notably clear-cut policy objectives, lacking strategic planning which would provide rationale and justification for selected policy objectives, mobilisation of spatial representation or lacking an element of broader binding mandate. In response to these shortcomings, the Barca Report proposed inner alia setting policy EU-level objective while acknowledging territorial cohesion, introducing set of conditionalities, or explicit territorial focus and architecture including multi-level governance. Even though, 'a place-based linguistic turn' (Mendez, 2013) attempted to position a place-based approach at the heart of the cohesion reform, the PBA eventually failed to inform the reform substantially. This was due prioritizing EU-level governance architecture in response to the financial and economic crisis (Jašurek, 2020a) as well as due to internal struggles between different DGs inside the Commission (Mendez, 2013) competing over their influence in bargaining the future financial perspective. Nevertheless, the PBA contributed to shape the 2013 reform towards policy's better result orientation or strategic planning and in the end to informing also the 2020 reform.

As in the case of the two previously depicted reforms from 2006 and 2013, a wider EU context was relevant for shaping the 2020 reform. First of all, the EU had faced different crises within rather the short period of time, notably Euro and immigration crises and Euroscepticism leading to the Brexit. Therefore, there was 
an evident continuity with the 2013 reform. First of all, cohesion mission was linked to the EU level strategic framework which was then borrowed from UN Sustainable Development Goals for 2030 (European Commission, 2017b: XXV). These were translated into the cohesion policy's condensed five policy objectives more or less alike to the previous 11 thematic objectives. Likewise, philosophy of earmarking remained its key principles from the 2013 reform. Furthermore, the reform package introduced also 80 simplifications measures aimed at e. g. reducing content duplicities between different programming documents or reducing requirements for updating programming documents. Integrated territorial instruments continued while they gained a new stimulus as political objective five 'a Europe closer to citizens' constituted the major platform for underpinning regional development and employment of the integrated territorial development. The shape of the 2020 reform was significantly marked by the outburst of the Covid-19 pandemic. Exogenous shocks typically cause abrupt insufficient liquidity leading to its equally abrupt increase. As in the aftermath of the financial and economic crises, the cohesion resources served this purpose. In the first step, the existing legislative framework was modified to increase liquidity e.g. by enabling more robust pre-financing, temporary 100\% co-financing, increasing investments in health sector or underpinning short-term employment schemes or de facto abolishing earmarking (European Union, 2020a; 2020b). These amendments signalled an intensified endeavours towards safeguarding liquidity in response to the recurring pandemic and the orchestrated drive to ensure the support of growth inducing sustainable development areas such digital and green agendas. The result was the new web of investment instruments under the common framework of the Next Generation EU (NextGen) 750 billion EUR for the period of 2021-2023. This was a recovery masterplan under the EU budget 2021-2027 devised to transform EU economies and societies to underpin their resilience against exogenous shocks and climate phenomena. Distribution of allocations between cohesion police and NextGen shows Table 1. Recovery and Resilience Fund (RRF) presents the flagship initiative under the NextGen composed of the combination of grants and loans. It underpinned major development reforms and investments carried out by member states. Thus, the RRF filled the gap as, there was 'no instrument foreseen direct financial support linked to the achievement of results and to the implementation of reforms and public investments' (European Union, 2021: 20). RRF aimed at mitigating negative aftermaths of the Covid-19 pandemic by increasing member states' sustainability, resilience and readiness notably for green and digital transformation. Distribution of allocations and responsibilities between cohesion policy and NextGen, notably the RRF shows interesting implications. First, while cohesion policy' mission remains significantly stretched as showed in Table 2, its allocation shrank. This may increase pressures on policy's effectiveness after 2020 in terms of its implementation and management. Second, as the EU budget 
cannot generate deficit, new income sources should be identified under the EU budget to cover loans such as introduction of new taxes e. g. from emissions or emissions trading schemes, digitisation, or financial transactions. Thirdly, as depicted in detail in the part on evolving governance, cohesion policy and the RRF offers also comparisons of the two distinctive management systems.

Impacts of the crises, namely immigration, Euro and Euroscepticism leading to the Brexit, shaped the contemplations on the developments in the EU. Most significantly, the Commission introduced the White Paper on the Future of Europe with the five development scenarios for the EU-27 by 2025 (for further details see European Commission, 2017a; Bachtler, Mendez and Wishlade, 2020; Jašurek a Šipikal, 2021b). White paper questioned cohesion policy's result delivery capacity when coordinated at EU level (European Commission, 2017a: 22). However, the Commission's Seventh Cohesion Report (2017b) reported a continuous growth in GDP per capita positively contributing to a decrease in regional disparities and unemployment rate in the entire EU. Tough disparities between the capitals and peripheral regions continued. White Paper questioned also performance of health sector and partially also social policy and employment while it highlighted benefits of digital agenda, energy, partially transport, defence and security and it supported in general also technological innovations. The prominence of these areas intensified after the outburst of the Covid-19 pandemic.

Table 1: Allocations distribution between cohesion policy and NextGen

\begin{tabular}{|c|c|c|c|c|}
\hline \multicolumn{2}{|c|}{ EU budget } & \multicolumn{3}{|c|}{ Next Gen } \\
\hline \multirow{2}{*}{\multicolumn{2}{|c|}{1074,3}} & \multirow[b]{2}{*}{750} & \multicolumn{2}{|c|}{390 (grants) } \\
\hline & & & \multicolumn{2}{|c|}{360 (loans) } \\
\hline $\begin{array}{l}\text { Cohesion policy } \\
\left(\mathrm{ERDF} / \mathrm{KF}, \mathrm{ESF}+{ }^{+}\right)\end{array}$ & 330.235 & \multirow{2}{*}{ RRF } & \multirow{2}{*}{672,5} & 312,5 (grants) \\
\hline \multirow[t]{6}{*}{ RRF } & 767 & & & 360 (loans) \\
\hline & & React-EU & \multicolumn{2}{|l|}{47,5} \\
\hline & 76,400 & Horizon Europe & \multicolumn{2}{|l|}{5} \\
\hline & 2,800 & Invest EU & \multicolumn{2}{|l|}{5,6} \\
\hline & 77,850 & Rural Development & \multicolumn{2}{|l|}{7,5} \\
\hline & 7,500 & $\begin{array}{l}\text { Just Transition } \\
\text { Fund (FST) }\end{array}$ & \multicolumn{2}{|l|}{10} \\
\hline & 1,106 & Rescue EU & \multicolumn{2}{|l|}{1,9} \\
\hline & & Total & \multicolumn{2}{|c|}{750 bln. EUR } \\
\hline
\end{tabular}

Source: European Commission 
Table 2: Evolving mission of cohesion policy
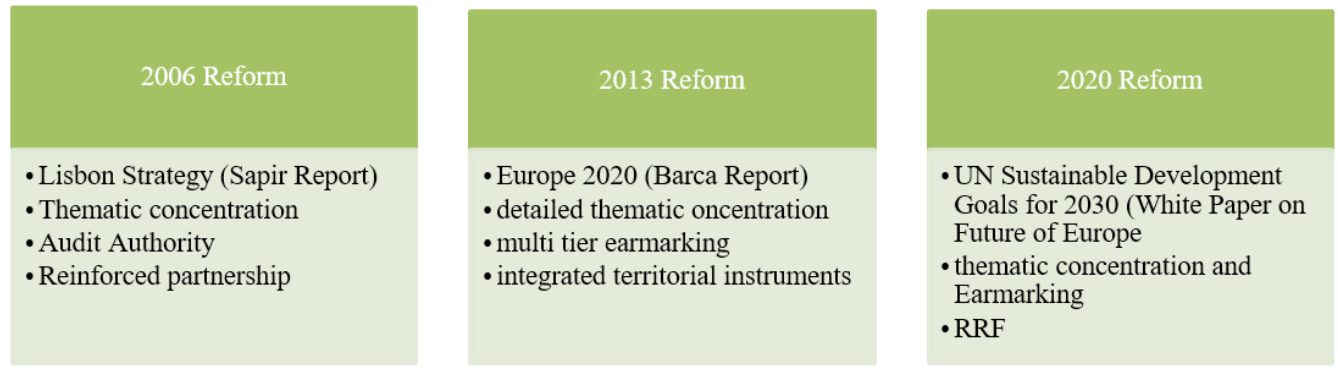

Source: Own elaboration

\subsection{Shaping the governance}

Beyond shaping cohesion policy's mission, its reforms has also brought evolution in governance. The linkage to the Lisbon agenda through the 2006 reform was ensured by means of the open method of coordination (OMC) as an attempt to employ soft governance principles. Its shortcomings (for detailed analysis see Mendez, 2013) contributed to expansion of hard governance in cohesion policy after 2013. OMC was developed to enable dissemination of best practice and achieving greater convergence towards the main EU goals. OMC was principally built on (European Council, 2000):

- fixing guidelines for the Union combined with specific timetables for achieving the goals which they set in the short, medium and long terms;

- establishing, where appropriate, quantitative and qualitative indicators and benchmarks against the best in the world and tailored to the needs of different Member States and sectors as a means of comparing best practice;

- translating these European guidelines into national and regional policies by setting specific targets and adopting measures, taking into account national and regional differences;

- periodic monitoring, evaluation and peer review organised as mutual learning processes.

OMC's operationalisation under the Lisbon agenda showed ambiguous results related to its operational ineffectiveness (Radulova, 2007) and also arguable reform stimulating potential (de la Porte and Pochet, 2012). OMC's limitations translated also to cohesion policy's major shortcomings in governance as introduced in the 2006 reform. Lisbonisation in cohesion policy meaning aligning cohesion policy with the Lisbon strategy introduced some important innovations which became policy's inherent part as of then. To align cohesion policy properly with the Lisbon agenda, the Commission introduced the Community Strategic Guideline for Cohesion, yet without EU-level enforced deadlines and targets 
(Mendez, 2011: 523). This showed to be critical exposing insufficient strategic planning and compelled the Commission to conclude in its assessment of the 2006 reform that policy's interventions ended up to be 'a shopping list of actions' (Mendez, 2011) instead of well-targeted investments.

The 2013 reform reflected shortcomings in governance from the 2006 reform. Reforms in governance focused on strategic planning and aligning cohesion policy more closely with wider EU governance. Commission's strategy notably in response to the financial and economic crisis was to reconnect cohesion policy with "the broader economic policy framework of the European Union" (Berkowitz et al., 2015:2). Similarly, the Barca Report also recommended to employ conditionalities more intensely in cohesion policy in order to improve the control over policy planning and conduct. Admittedly, conditionalities have been an indispensable part of cohesion policy as of 1988. On the other hand, the 2013 reform brought new opportunities by introducing novel conditionalities, ex ante and macroeconomic conditionalities. Although, the latter were not brand new by definition as they applied to the Cohesion Fund in the programming period 200720013. For different types of cohesion conditionalities see Bachtler and Mendez, 2020a; Jašurek, 2020a; Jašurek a Šipikal, 2021b).

The major distinctive feature of the two from the rest of cohesion conditionalites was their straightforward linkage to the EU level governance. They constituted 'a part of wider EU endeavours to rebuild economic governance after 2009 as a response to aftermaths of the financial and economic crisis... built notably on the two pillars' (Jašurek and Šipikal, 2021a: 5). The first pillar, ex-ante conditionalities were growth inducing measure via the formal EU level recommendations under the European Semester, 'a framework to improve EU economic policy coordination’ (Hallerberg et al., 2012: 2). They linked reform national policy priorities to EU level requirements. The second pillar, macroeconomic conditionalities focused on mending economic imbalances by means of the EU level macroeconomic surveillance. Bargaining both conditionalities as part of the 2013 reform was challenging. Admittedly, exante conditionalities were recognized positively also in scholarship (McCann, 2015; Bachtler et al., 2017; Huguenot-Noël et al., 2017). Quite the opposite, macroeconomic conditionalities spurred intense controversies. Some scholars rejected them altogether (Jouen, 2015; Huguenot-Noël et al., 2017) while others found macroeconomic conditionalities a worthy research subject (Coman, 2018; Sacher, 2019). A solidly balanced account on the role of conditionalities per se in cohesion policy provided Bachtler and Mendez (2020a).

Evidently, introducing conditionalities was not an easy task, notably in case of those related to macroeconomic stability. On one hand, there was an overwhelming support by the Commission and the EU-15 (Coman, 2018, p. 547; Mendez et al., 2013, p. 10), on the other the Committee of Regions (2011) 
and notably the Parliament as the co-legislator (2012a, 2012b, 2013) severely resisted introduction of macroeconomic conditionalities. Both feared unbalanced and unfair impacts of suspensions on European regions. In the end however, the Parliament conceded upon the insertion of the structured dialogue, yet without any substantial amendments to suspensions or details on the conduct of the structured dialogue, a communication platform requiring the Commission to inform the legislators on the sanctioning process. Similarly, suspensions provisions on exante conditionalities were bargained at length leaving other provisions without sufficient details (Jašurek and Šipikal, 2021a).

Shortcomings in implementation of conditionalities reflected outcomes of bargaining which focused considerably on the punitive means of the suspensions in both conditionalities. As a result, Commission's passivity, presumably due to internal contentions over perceived reputational risks associated with imposing punitive means in the atmosphere of rising Euroscepticism, enabled arbitrary interpretation of conditionalities' rules. Consequently, member states applied self-suspensions, against the formal rules on ex-ante conditionalities in order to avoid stricter Commission's suspensions. Furthermore, an ambiguous link to the European Semester, a policy cycle coordination mechanism to meet those formal Council's recommendations (Jašurek and Šipikal, 2021a) led to inconsistent member states' self-assessment as well as Commission's assessment of ex-ante conditionalities fulfilment (for more details on implementation see European Commission. 2016a and 2017c; European Court of Auditors, 2017b; Coman, 2018; Sacher, 2019; Jašurek and Šipikal, 2021). In nutshell, conditionalities as new governance instruments introduced in the 2013 reform showed some delivery promises though their design was far from being completed (Jašurek and Šipikal, 2021: 19).

The 2020 reform package marked continuity with the 2013 reform while addressing its operational shortcomings as shows Table 3. Thus ex-ante conditionalities were transformed into enabling conditions with an improved linkage to the European Semester by tying their enabling conditions' requirements to the Council's recommendations and fulfilment is to be carried out throughout the entire implementation unlike previously only 'ex ante', meaning prior the implementation. Punitive means of suspensions of payments were replaced by softer postponed reimbursements in case of non-fulfillment. Similarly, macroeconomic conditionalities were approved despite the initial opposition by the Parliament (Pucher, Martinos, Pazos-Vidal \& Haider 2019: 50). Furthermore, conditions for suspensions watered down and as of 2021 they are related to commitments rather than payments.

After the Covid 19 outbreak and introduction of the RRF, the use of macroeconomic conditinalities was enhanced also here. Importantly, as hinted in the part on the cohesion policy mission designed in the 2020 reform, comparison 
of the RRF and cohesion policy offers the two distinctive perspective on the management systems. While cohesion policy's management is based on the shared responsibility between member states and the Commission stemming from the Lisbon Treaty, the RRF is managed solely by the Commission. Its control responsibilities are thus significantly enhanced. There are twofold reasons for this shift in management responsibilities towards enforcing the Commission. First, the RRF implementation is conducted within much shorter timespan relative to the cohesion policy seven year cycle. This increases the pressure on implementation efficiency and its governance. Secondly, Commission's strengthening role may be perceived as a result of cohesion policy's critique from the Commission's top levels as was the case of the White paper discussed before or Commission President Juncker' distaste for cohesion policy expressed either by avoiding any reference of this major EU budgetary chapter in his State of the Union Reports or allowing unbalanced critical comparisons between cohesion policy and Commission's managed Juncker plan (European Commission, 2016b).

\section{CONCLUSION}

The three cohesion reforms (2006, 2013, and 2020) significantly shaped policy's mission and governance. The former's design became more detailed and closely linked to the EU level objectives as stemming from the EU strategies and the commissioned reports. The latter as shown in Table 3 marked the introduction of conditionalities in the 2013 reform as the EU level control mechanisms and thus increasingly strengthened the role of the Commission and the shifting away from the soft governance. Other governance elements such as the partnership principle have been only mildly regulated by the Commission leaving considerable room for member states to design ways to promote partnership (for a practical example on the conduct of partnership see Jašurek, 2020b on the case study from Slovakia). The three reforms underlined policy's transformation from the merely redistributive tool with limited budgetary resources into the full-fledged development policy aimed at safeguarding that EU's visions and goals will be pursued. On the other hand, this however shows that notably after 2020 cohesion policy retains its mission stretched with tightening governance while its budget is constrained due to new instruments particularly the RRF. Cohesion policy thus ends up doing more with less money (Bachtler and Mendez, 2020b). This appear to be the major challenge for cohesion policy after 2020 . 
Table 3: Evolving governance of cohesion policy
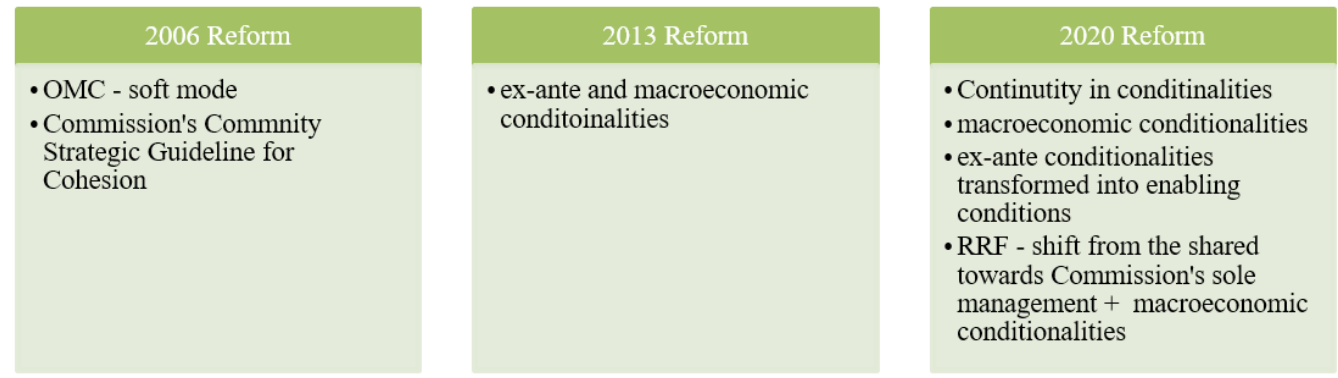

Source: Own elaboration

\section{REFERENCES}

AHNER, D. 2009. What do you really know about European cohesion policy? Notre Europe, 2009, pp. 1-10, Dostupné na internete: https://institutdelors.eu/ wp-content/uploads/2018/01/ecp_rational_and_objectives.pdf

ALLEN, D. 2005. Cohesion and the Structural Funds. Competing Pressures for Reform? In Wallace, H., Wallace, W. and Pollack, M. Policy-making in the European Union, 2005, Oxford University Press: Oxford and New York. ISBN-10 0199276129.

BACHE, I. 2014. Cohesion Policy: New Direction for New Times? In Wallace, H., Pollack, M.A., Young, A. R., Policy-making in the European Union, 2014, Oxford University Press: Oxford, New York, ISBN-10 0199689679.

BACHTLER, J., BERKOWITZ, P., HARDY, S. and MURAVSKA, T. 2017. Introduction. Reassessing the performance and direction of EU Cohesion Policy in 2014-20. In

BACHTLER, J., BERKOWITZ, P., HARDY, S., \& MURAVSKA, T. (Eds.). EU Cohesion Policy. Reassessing performance and direction. New York: Routledge, 2017, 1-9, ISBN 9780367668020.

BACHTLER, J. and MENDEZ, C. 2020a. Cohesion and the EU Budget: Is Conditionality Undermining Solidarity? In COMAN, R., CRESPY, A. and SCHMIDT, V. (Eds.). Governance and Politics in the Post-Crisis European Union. Cambridge: CUP, 2020, pp. 121-140, ISBN: 9781108482264.

BACHTLER, J. and MENDEZ, C. (2020b). Cohesion Policy: Doing More With Less. In WALLACE, H., POLLACK, M., ROEDERER-RYNNING, C., and YOUNG, A. (Eds.). Policy-Making in the European Union. Oxford: OUP, 2020, pp. 232-253, ISBN: 9780198807605.

BACHTLER, J., MENDEZ, C. amd WISHLADE, F. 2020. Will Cohesion Policy Recover From COVID? An Initial Assessment, European Regional Policy Research Consortium Paper 20/3. European Policies Research Centre: Glasgow and Delft. 2020, 47 p, ISBN: 978-1-909522-84-8. 
BARCA, F. 2009. An Agenda for a Reformed Cohesion Policy. A Placebased Approach to Meeting European Union challenges and expectations. Independent Report at the Request of Danuta Hübner, Commissioner for regional Policy by Fabrizio Barca, Brussels. Dostupné na internete: https:// ec.europa.eu/regional_policy/archive/policy/future/pdf/report_barca_v0306. pdf

BARCA, F., McCANN, P., RODRIGUEZ-POSE, A. 2012. The case for regional development intervention: place-based vs place-neutral approaches. In: Journal of Regional Science 52, no. 1, 2012, pp. 134-152, Dostupné na internete: https://doi.org/10.1111/j.1467-9787.2011.00756.x.

BARNIER, M. 2003. The Future of European Regional Policy. In: EU Cohesion Policy: Challenges and Responses Intereconomics, Review of European Economic Policy, vol. 38, no. 6, 2003, 292-295, Dostupné na internete: https:// www.intereconomics.eu/contents/year/2003/number/6/article/eu-cohesionpolicy-challenges-and-responses.html.

BAUN, M. and MAREK, D. 2014. Cohesion Policy in the European Union. New York: Palgrave Macmillan, 2014, 272 p., ISBN13 9780230303140.

BERKOWITZ, P., BRESKA, E. V., PIENKOWSKI, J. and RUBIANES, A. C. 2015. The Impact of the Economic and Financial Crisis on the Reform of Cohesion Policy 2008-2013, Regional Working Paper 03/2015, DirectorateGeneral for Regional and Urban Policy, Brussel, 28 p, Dostupné na internete: https://ec.europa.eu/regional_policy/en/information/publications/workingpapers/2015/the-impact-of-the-economic-and-financial-crisis-on-the-reformof-cohesion-policy-2008-2013.

BRUNAZZO, M. 2016. The History and Evolution of Cohesion Policy. In Piattoni, S. and Polverari, L. Handbook on Cohesion Policy in the EU. Edward Elgar Publishing Limited: Cheltenham and Northampton, 2016, ISBN-10 1784715662.

COMAN, R. 2018. How Have EU 'Fire-Fighters' Sought to Douse the Flames of the Eurozone's Fast- and Slow-Burning Crises? The 2013 Structural Funds Reform. The British Journal of Politics and International Relations, 2018, vol. 20, pp. 540-554, ISSN: 1467-856X.

DE LA PORTE, C. and POCHET, P. 2012. Why and how (still) study the Open Method of Co-ordination (OMC)? Journal of European Social Policy. vol. 22, no. 3, pp. 336-349, Dostupné na internete: https://doi. org/10.1177/0958928711433629

EUROPEAN COMMISSION. 2003. An Agenda for a Growing Europe, Making the EU Economic System Deliver, Report of an Independent High-Level Study Group established on the initiative of the President of the European Commission. Chairman of the Group André Sapir, Brussels, Dostupné na internete:https://www.researchgate.net/publication/227467942_An_Agenda_ 
for_a_Growing_Europe_The_Sapir_Report.

EUROPEANCOMMISSION. 2004. Facing the Challenge, The Lisbon Strategy for Growth and Employment. Report from the High Level Group chaired by Wim Kok, Publications Office of the European Union: Luxembourg, Dostupné na internete: https://op.europa.eu/en/publication-detail/-/publication/88b6bc81e3ad-4156-960f-f549369aa9d4, ISBN 92-894-7054-2

EUROPEAN COMMISSION. 2010. Communication from the Commission. Europe 2020. A strategy for smart, sustainable and inclusive growth. COM(2010) 2020, Dostupné na internete: https://ec.europa.eu/eu2020/pdf/ COMPLET\%20EN\%20BARROSO\%20\%20\%20007\%20-\%20Europe\%20 2020\%20-\%20EN\%20version.pdf

EUROPEAN COMMISSION. 2016a. The Implementation of the Provisions in Relation to the Ex-ante Conditionalities During the Programming Phase of the European Structural and Investment (ESI) Funds. Final report, DirectorateGeneral Regional and Urban Policy, Brussels, 2016, 147p, ISBN 978-92-7959496-0.

EUROPEAN COMMISSION. 2016b. Communication from the Commission to the European Parliament and the Council .Mid-term review/revision of the multiannual financial framework 2014-2020 An EU budget focused on results. SWD(2016) 299 final, 69 p, Dostupné na internete: https://ec.europa. eu/info/sites/default/files/about_the_european_commission/eu_budget/swd2016-299_en.pdf.

EUROPEAN COMMISSION. 2017a. White Paper on the Future of Europe. Reflections and scenarios for the EU27 by 2025. Brussels: Publications Office of the European Union, 2017, p. 32, ISBN: 978-92-79-67652-9.

EUROPEAN COMMISSION 2017b. My Region, My Europe, Our Future. Seventh Report on Economic, Social and Territorial Cohesion. Luxembourg: Publications Office of the European Union, 2017, 249 p, ISBN 978-92-7971834-2.

EUROPEAN COMMISSION. 2017c. Commission Staff Working Document. The Value Added of Ex Ante Conditionalities in the European Structural and Investment Funds. SWD(2017) 127 final, 31 March, Brussels, Dostupné na internete: https://ec.europa.eu/regional_policy/sources/docgener/studies/pdf/ value_added_exac_esif_en.pdf

EUROPEAN COUNCIL 2000. Presidency Conclusions. 23-24 March, Lisbon, Dostupné na internete: https://www.europarl.europa.eu/summits/lis1_en.htm EUROPEAN COURT OF AUDITORS. 2017b. Ex Ante Conditionalities and Performance Reserve in Cohesion: Innovative but not Yet Effective Instruments. Special Report no. 15, European Union: Luxembourg, Dostupné na internete: https://www.eca.europa.eu/Lists/ECADocuments/SR17_15/SR_ PARTNERSHIP_EN.pdf. 
EUROPEAN PARLIAMENT. 2012a. Cohesion policy after 2013: A critical Assessment of the Legislative Proposals. Directorate-General for internal policies, Policy department B: Structural and cohesion policies. Regional development, European Union: Brussels, Dostupné na internete: https://www. europarl.europa.eu/RegData/etudes/etudes/join/2012/474558/IPOL-REGI_ ET(2012)474558_EN.pdf.

EUROPEAN PARLIAMENT. 2012b. Report on the Proposal for a Regulation of the European Parliament and of the Council on the European Social Fund. A70250/2012, Committee on employment and social affairs, Brussels, Dostupné na internete: https://www.europarl.europa.eu/doceo/document/A-7-2012-0250_ EN.html.

EUROPEAN PARLIAMENT. 2013. Report on Common Provisions Regulation. A7-0274/2013, Committee on regional development, Brussels, Dostupné na internete: https://www.europarl.europa.eu/doceo/document/A-7-2013-0274 EN.html.

EUROPEAN UNION. 2012. Treaty on the Functioning of the European Union. Official Journal of the European Union.

EUROPEAN UNION. 2020a. Regulation (EU) 2020/460 as regards specific measures to mobilise investments in the healthcare systems of Member States and in other sectors of their economies in response to the COVID-19 outbreak (Coronavirus Response Investment Initiative). Official Journal of the European Union, OJ L 99.

EUROPEAN UNION. 2020b. Regulation (EU) 2020/558 as regards specific measures to provide exceptional flexibility for the use of the European Structural and Investments Funds in response to the COVID-19 outbreak. Official Journal of the European Union, OJ L 130.

EUROPEAN UNION. 2021. Regulation (EU) 2021/241 establishing the Recovery and Resilience Facility. Official Journal of the European Union, OJ L 57.

FAROLE, T., RODRIGUEZ-POSE, A., STORPER, M. 2011. Cohesion Policy in the European Union: Growth, Geography, Institutions. In: Journal of Common Market Studies, Vol. 49, No. 5, 2011, pp. 1089-1111, ISSN 0021-9886.

HALLERBERG, M., MARZINOTTO, B. and WOLFF, G. B. 2012. On the Effectiveness and Legitimacy of EU Economic Policies. Bruegel Policy Brief. Brussels, 8p, Dostupné na internete: https://www.bruegel.org/wp-content/ uploads/imported/publications/pb_2012-04_final.pdf.

HUGUENOT-NOëL, R., HUNTER, A., \& Z ZULEEG, F. 2017. Can the EU structural funds reconcile growth, solidarity and stability objectives? A study on the role of conditionalities in spurring structural reforms and reducing macroeconomic imbalances. European Policy Centre, Issue Paper No. 83, October, Brussels, 32 p, Dostupné na internete: http://aei.pitt.edu/91832/1/ pub_7998_cohesionpolicyissuepaper.pdf 
JAŠUREK, I. 2020a. The Place-based Approach and the 2013 EU Cohesion Reform. Mission Impossible. In Proceedings of the 2020 23th Edamba International Scientific Conference for Doctoral Students and Post-Doctoral Scholars From better economics to better economy. University of Economics in Bratislava. pp. 312-334, ISBN 978-80-225-4794-9

JAŠUREK, I. 2020b. Information and Consltancy Centres in Slovakia. Promoting

Partnership in Cohesion Policy. In: Leadership, Innovation, Management and Economics: Integrated Politics of Research. Conference Proceedings. OnlineVirtual November 26, 2020, pp. 141-151, ISSN 2683-6149

JAŠUREK, I. and ŠIPIKAL, M. 2021a. Examining conditionalities in Cohesion

Policy: an application of the principal-agent framework. Territory, Politics, Governance. pp. 2-24, Dostupné na internete: https://doi.org/10.1080/216226 71.2021.1954988.

JAŠUREK, I. a ŠIPIKAL, M. 2021b. Politika súdržnosti Európskej únie. Bratislava: Ekonóm, 2021, 132 s., ISBN 978-80-225-4822-9.

JOUEN, M. 2015. The macro-economic conditionality, the story of a triple penalty for regions. Jacques Delors Institute, 31 March 2015, 1-10, Dostupné na internete: https://institutdelors.eu/wp-content/uploads/2020/08/ macroeconomicconditionnality-jouen-jdi-march15-1.pdf.

MANZELLA, G. P. and MENDEZ, C. 2009. The Turning Points of EU Cohesion Policy. European Investment Bank: Luxembourg, Dostupné na internete: https://ec.europa.eu/regional_policy/archive/policy/future/pdf/8_manzella_ final-formatted.pdf

MCCANN, P. 2015. The Regional and Urban Policy of the European Union cohesion, results-orientation and smart specialisation. Cheltenham: Edward Elgar Publishing, 2015, 304 p, ISBN: 9781783479504.

MENDEZ, C. 2011. The Lisbonization of EU Cohesion Policy: A Successful Case of Experimentalist Governance? European Planning Studies. Vol. 3, 19p. Dostupné na internete: http://dx.doi.org/10.1080/09654313.2011.548368. MENDEZ, C. 2013. The post-2013 reform of EU cohesion policy and the placebased narrative. Journal of European Public Policy, Vol. 20, No. 5, 2013, pp. 639-659, Dostupné na internete: http://dx.doi.org/10.1080/13501763.2012.7 36733.

MENDEZ, C., WISHLADE, F., and BACHTLER, J. 2013. Negotiating boxes and blocks: Crafting a deal on the EU budget and Cohesion Policy. EoRPA Paper, 2013 vol. 12, no. 4, European Policy Research Paper no. 82, University of Strathclyde: Glasgow, ISBN:1-871130-88-3.

PUCHER, J., MARTINOS, H., PAZOS VIDAL, S., and HAIDER, J. 2019. Research for REGI Committee - Cohesion Policy: European Parliament Role Since the Treaty of Lisbon, European Parliament. Policy Department for Structural and Cohesion Policies. Brussels, 2017, 74p, ISBN 978-92-846- 
4877-1.

RADULOVA, E. 2007. Variations on Soft EU Governance: The Open Method(s) of Coordination. In De BIÈVRE, D. and NEUHOLD, C. (eds.). Dynamics and Obstacles of European Governance. Cheltenham, Northampton: Edward Elgar Publishing, 2007, pp. 3-27, ISBN: 9781847200341.

SACHER, M. 2019. Macroeconomic Conditionalities: Using the Controversial Link Between EU Cohesion Policy and Economic Governance. Journal of Contemporary European Research, 2019, vol. 15 no. 2, pp 179-193, Dostupné na internete: https://doi.org/10.30950/jcer.v15i2.1005.

SINGLE EUROPEAN ACT. 1987. No L 169/1, Official Journal of the European Union.

STAHL, G. and LUNA, D. 2003. A Cohesion Policy for Future. In: EU Cohesion Policy: Challenges and Responses Intereconomics, Review of European Economic Policy, vol.38, num. 6, 2003, 295-301, Dostupné na internete: https://www.intereconomics.eu/contents/year/2003/number/6/article/eucohesion-policy-challenges-and-responses.html 